between which ran a row of whitish spots and no rusty or orangecoloured markings near the cornicles.

Davis in his recent paper (Bull. 112, U. S. Dept. Agri., 1914) points out that in America avence also passes the winter as viviparous females at the lower parts and roots of wheat and other grasses. In the latitude of La Fayette, Indiana, it winters either as viviparous females on grain and grasses or in the egg stage on apple and pear. Further north, he says, this species is probably unable to winter in any but the egg stage, whilst in the southern parts of the United States they may live over winter as viviparous females only, no egg stage appearing. He thus concludes that the apple is not a necessary alternate host. In a recent letter to me this authority thinks that my Siphocoryne splendens from Egypt* may be the same as avence, but it differs markedly in structure, and I have never seen avence crimson and green in Britain, but Professor Davis says it may be so in America.

\title{
DESCRIPTIONS OF AND OBSERVATIONS ON SOME CHALCIDOID HYMENOPTERA.
}

BY A. A. GIRAULT, GLENNDALE, MD.

\section{Eupelmus marylandicus, n. sp.}

Female-Length $1.95 \mathrm{~mm}$., excluding the ovipositor valves, which are straight, compressed somewhat and extruded for a length equal to somewhat over half that of the abdomen. Slender, graceful. Allied to the Australian pachyscapha.

Dark metallic purple, the tarsi except the last joint, tips of tibiæ narrowly and the distal half (or a little more) of the middle tibia, white or nearly. Fore wings brown from the proximal end of the bend of the submarginal vein distad to apex, the infuscation broken by two distinct, straight, longitudinal, hyaline stripes, the cephalic and shorter from the base of the stigmal vein to apex and including the cephalic wing margin; the other much longer, extending from a point caudad of middle, nearly opposite the middle of the marginal vein to the apex. Stigmal vein slender, nearly two-thirds the length of the postmarginal. Antennæ inserted about

${ }^{*}$ Bull. Ent. Res.

July, 1916 
in the middle of the face, but below the ventral ends of the eyes, the latter shorter than the cheeks. Scape greatly, rectangularly dilated (over twice longer than wide, excluding the bulla); pedicel somewhat longer than wide at apex, subequal to funicle 5 ; funicle 1 , or the "ring-joint," a little wider than long; 2 over twice longer than wide, 3 and 4 subequal, longest, a little longer than $2 ; 8$ a little longer than wide, subequal to club 1. Mandibles tridentate. Wings rather slender. Cephalic raised piece of scutum and the lateral ridge weak, yet distinct. Axillæ small, convex barely separated, or not at all; scutellum globular, convex. Pronotum quadrate. Abdomen a third longer than the thorax. Sculpture weak. Cephalic femur compressed. Middle tarsi with black teeth beneath.

Described from one female captured by sweeping in the forest, Chevy Chase Lake, Maryland, April 24, 1915.

Type-Catalogue No. 20094, U.S. N. M., the above female on a tag, the head and a fore wing on a slide.

\section{Eupelmus speciosus, n. sp.}

Female-Length $2.00 \mathrm{~mm}$., the ovipositor valves shortly extruded.

Light orange yellow, the wings hyaline or sometimes slightly infuscated under the marginal vein, the head dark metallic green (except the mouth) as is also the distal third of the scutellum; legs, ovipositor valves and scape pale yellow. Pedicel suffused with yellow; rest of antenna black. Scape a little compressed; pedicel twice longer than wide at apex, longer than any of the funicle joints, of which 4 is longest, nearly twice longer than wide; 1 wider than long, 2 a fourth longer than wide, 3 next longest, 8 somewhat wider than long. Postmarginal vein but very slightly longer than the stigmal. Head, axillæ and scutellum densely scaly, rest of thorax delicately so. Lateral ridges of scutum joined across near caudal margin, the raised triangular piece reaching to about the middle. Ovipositor valves black at extreme base. Abdomen narrowing gradually to apex, as long as the rest of the body combined. Middle tarsi with black teeth beneath.

Described from seven females in the collection of the U. S. National Museum, on tags bearing the following label: " $4841^{011}$, April 3, 1890." Locality, Washington, D. C.? 
Types-Catalogue No. 20091, U. S. N. M., the above specimens, a pair of antennæ on a slide.

\section{Eupelmus cyaniceps Ashmead utahensis, new variety.}

Female-Length $2.00 \mathrm{~mm}$., excluding the ovipositor, which is two-thirds the length of the abdomen.

Differs from the description of rosa Ashmead in having the cephalic femur metallic. Differs from cleri in having the postmarginal vein no longer than the stigmal and the ovipositor valves broadly dusky at tips; runs to cyaniceps Ashmead, but differs in being much less robust, in having the cephalic tibiæ nearly wholly metallic. Caudal legs metallic (except tarsi); middle tibiæ yellow, also the femur except proximad more or less. Funicle 1 much wider than long, 2 and 3 subequal, longest, each about twice longer than wide.

Described from two females in the collection of the U.S. N. M., from American Fork, Utah, July.

Types-Catalogue No. 20092, U. S. N:M., the above specimens on tags, a head and fore wing on a slide.

Compared with types of cleri and cyaniceps. Middle white portion of ovipositor much longer than the basal blue portion, shorter than the distal dusky portion.

\section{Eupelmus cyaniceps Ashmead amicus, new variety.}

Female-Like the typical form, but the ovipositor valves more slender and the white middle portion shorter than either basal or distal portion (in the typical form the yellowish middle portion is longest.)

Described from three pairs on tags in the U. S. N. M., labelled: "From Bruchus amicus Horn, Las Cruces, New Mexico."

Types-Catalogue No. 20098, U. S. N. M., the above specimens (three tags).

\section{Eupelmus charitopoides, new species.}

Female-Length $1.85 \mathrm{~mm}$., excluding the ovipositor, which is extruded for a length equal to that of the abdomen.

Dark metallic green, the wings subhyaline; tarsi, knees, tips of cephalic tibia, distal half of caudal tibiæ and middle tibiæ except 
a cinctus just below the knee, reddish brown; teeth of middle tarsus ventrad white, dense, soft. Venation yellow. Postmarginal vein nearly twice the length of the stigmal, which is moderately long. Head and thorax very delicately scaly. Axillæ barely separated inwardly. Lateral ridges of scutum distinct, the raised cephalic, mesal portion small. Antennæ inserted below the middle of the face, slightly below the ventral ends of the eyes; scape distinctly much compressed; pedicel twice longer than wide at apex, subequal to funicle 5 ; funicle 1 slightly longer than wide, 2 and 4 longest, each about thrice longer than wide, 8 thickest, about a half longer than wide. Differs from Charitopus schwariii Ashmead in being shorter, the stigmal vein is twice longer, the legs differently coloured and so on.

Described from one female in the U. S. N. M. from Harper's Ferry, West Virginia, May 19.

Type-Catalogue No. 2009', U.S. N. M., the above specimens on a tag, an antenna on a slide.

Scutellista cyanea, Motschoulsky.

Several pairs reared from Ceroplastes galeatus Newstead, Kampala, Uganda, Africa, September 6, 1915 (C. C. Gowdey).

\section{Eurytoma galeati, new species.}

Female-Length $1.95 \mathrm{~mm}$. Abdomen as long as the rest of the body.

Agrees with the description of transvaalensis Cameron, except as follows: The scape is entirely reddish, the middle and caudal tibiæ each bear a distinct, middle black cinctus; the marginal vein is distinctly somewhat longer than the postmarginal. On the depressed basin of the propodeum, which is reticulated, there is a nearly half complete-median channel composed of two foveæ end to end on each side of a very narrow median carina. Club 2 -jointed; funicles 4 and 5 each somewhat longer than wide, longer than the pedicel. Abdominal petiole a little wider than long. Segment 5 of abdomen longest, equal to 3 and 4 united, abdomen dorsad glabrous, finely scaly distad of segment 5 and on the lateral aspect. Mesopleurum finely punctate, caudal half finely striate cepholo-caudad. Prepectus mostly glabrous. Punctures dense, 
distinct. Distal segment of abdomen long-pointed. Stigmal vein slightly shorter than the postmarginal. Funicle 1 somewhat over half the length of the body of the scape.

Described from two females reared from Ceroplastes galeatus Newstead, Kampala, Uganda, Africa (C. C. Gowdey), September, 1915 .

Types-Catalogue No. 2009:, U. S. N. M., the above specimens on tags, plus a slide bearing antennæ, a fore wing, caudal legs, a fore leg and a middle tibia.

Aphelinus automatus Girault.

A female, Vienna, Virginia, from Aphis setaria (W. F. Turner).

Coelopisthia confusa, new species.

Female-The same in stature, and so forth, as fumosipennis Gahan, but differing as follows: The legs (excluding the concolorous coxæ) are darker, being reddish; the antennæ are inserted a little higher up on the face and differ notably in that the ring-joints are normal (that is not large, the second not subquadrate), the scape is red, the pedicel nearly all dusky black, funicle 1 a little wider than long, 4-6 subequal, much wider than long; the infuscation of the fore wing is fainter and more diffused, yet distinct. At least one mandible 4-dentate (other not seen). Flagellum black.

Described from one female in the collections of the U.S. N. M., labelled "Semiotellus chalcidiphagus Walsh., Washington, D. C." This species, superficially, is very similar to Homoporus crassinervis Thomson.

Type-Catalogue No. 20096, U. S N. M., the above female on a tag, a pair of wings, a caudal tibia and the antennæ on a slide.

\title{
A NEW GENUS OF PTEROMALID CHALCIDOID HYMENOPTERA FROM NORTH AMERICA.
}

\author{
BY A. A. GIRAULT, GLENNDALE, MD.
}

Tomocerodes, new genus.

Female.-Belongs to the Eunotinæ. Like Tomocera Howard, except that the caudal tibia is armed with a very long, stout spur, 


\section{$2 \mathrm{BHL}$ Biodiversity Heritage Library}

Girault, Alexandre Arsène. 1916. "Descriptions of and observations on some chalcidoid Hymenoptera." The Canadian entomologist 48, 242-246.

View This Item Online: https://www.biodiversitylibrary.org/item/18797

Permalink: https://www.biodiversitylibrary.org/partpdf/1027

\section{Holding Institution}

MBLWHOI Library

\section{Sponsored by}

MBLWHOI Library

\section{Copyright \& Reuse}

Copyright Status: NOT_IN_COPYRIGHT

This document was created from content at the Biodiversity Heritage Library, the world's largest open access digital library for biodiversity literature and archives. Visit BHL at https://www.biodiversitylibrary.org. 